\title{
A new recombinant in the heteromorphy ' $S$ ' supergene in Primula
}

\author{
VALSA KURIAN \& A. J. RICHARDS* \\ Department of Agricultural and Environmental Science, Ridley Building, University of Newcastle upon Tyne \\ NE1 TRU, U.K.
}

\begin{abstract}
A novel heteromorphic phenotype, $\mathrm{P}^{*}$, in Primula $\times$ tommasinii differs from long-styled ('pin') morphs, half the pollen having a size distribution typical of pins and the other half a distribution typical of short-styled 'thrums'. All $\mathrm{P}^{*}$ pollen is compatible with pin mothers, and is compatible on $\mathrm{P}^{*}$ stigmas, but is incompatible with thrum mothers. However, as a mother, $\mathrm{P}^{*}$ shows the same compatibility relationships as do pins. The $\mathrm{P}^{*}$ phenotype is inherited as a single dominant factor. All $\mathrm{P}^{*}$ plants are heterozygous for the recessive 'pin' chromosome, but the offspring of $\mathrm{P}^{*}$ selfs give ratios of $2: 1 \mathrm{P}^{*}$ : pin, rather than 3:1. All $\mathrm{P}^{*}$ plants have styles, stigmatic papillae and style cells shorter than pins, but much longer than in thrums. We conclude that this phenotype results from a recombination within the heteromorphy supergene between a locus which controls pollen size and one which controls dominance for pollen size. On the $\mathrm{P}^{*}$ recombinant chromosome we suggest that loci controlling female compatibility and style length (in part) $(\mathrm{G} / \mathrm{g})$, anther position $(A / a)$, and pollen size dominance $(\mathrm{Mpm} / \mathrm{mpm})$ carry recessive, pin-linked alleles; whereas those controlling pollen size $(P p / p p)$, male compatibility $(\mathrm{Pm} / \mathrm{pm})$, and style length (in part) $(\mathrm{Gm} / \mathrm{gm})$ carry dominant, thrum-linked alleles. A recessive, thrum-linked lethal $l$ is also linked to this part of the chromosome. Thus, it appears that at least seven loci control the Primula heteromorphy supergene. We also show for the first time in Primula the independence of pollen size from male incompatibility, and that pollen size is under gametophytic control, dominance for this character being controlled by a recombinable locus. We also confirm earlier suggestions that style length, stigma papilla length and style cell length are developmentally correlated, and are controlled by at least two loci with additive effects, that genes controlling male and female compatibility are recombinable, and that a recessive lethal gene is linked to the thrum chromosome.
\end{abstract}

Keywords: heteromorphy, incompatibility, lethal gene, Primula, recombination, supergene.

\section{Introduction}

About 90 per cent of the 425 species of Primula are distylous, the style length dimorphism being genetically linked to dimorphisms for anther position and pollen size (Wedderburn \& Richards, 1992). Longstyled ('pin') flowered plants have small, numerous pollen and anthers placed low in the corolla tube, whereas short-styled ('thrum') flowered plants have larger, less numerous pollen and anthers placed at the mouth of the corolla tube. Other dimorphic features of stigma shape, stigma papilla length and

\footnotetext{
*Correspondence. E-mail: a.j.richards@ncl.ac.uk
}

style cell length are thought to be developmental correlates of distyly (Al Wadi \& Richards, 1993; Richards, 1993).

A diallelic self-incompatibility system is also linked to dimorphic features in Primula. Homostyle recombinants show that the genetic control of illegitimate pollen recognition is associated with the locus controlling pollen size on the male side, and with the locus controlling style length on the female side. The work of Ernst (1955), reanalysed by Dowrick (1956), Ernst (1957), Richards (1986) and Lewis \& Jones (1993), and confirmed in part by Wedderburn \& Richards (1992), shows that this coadapted linkage group 'supergene' contains at least three recombinable loci. These have been termed 
$1 \mathrm{G} / \mathrm{g}$, which controls style length and associated features, together with incompatibility recognition (female side);

$2 P / p$, which controls pollen size, and incompatibility recognition (male side); and

$3 A / a$, which controls anther position.

Thrum-linked features are genetically dominant to pin-linked features, so that thrums are heterozygotes GPAlgpa and pins are homozygotes gpa/gpa. Although the thrums of many species are moderately self-fertile (Wedderburn \& Richards, 1990), true breeding thrums $G P A / G P A$ rarely occur, having been reported only in $P$. sinensis Sabine, suggesting that a recessive sublethal (Mather \& De Winton, 1941) or lethal (Lewis \& Jones, 1993; Richards 1993) gene may be linked to the thrum GPA chromosome. This suggestion is supported by the finding that long homostyle primrose $(P$. vulgaris Hudson) homozygotes $g P A / g P A$ are less viable than are homostyle heterozygotes $g P A$ /gpa (Crosby, 1949). In this case, a (sub)lethal locus may be linked to $P A$ rather than to $G$ (Richards, 1993).

Although thrum plants are heterozygous, segregating pollen grain genotypes GPA and gpa, until now all thrum primulas have shown only one pollen grain phenotype for size and mating type, namely $\mathbf{P}$ (large pollen, thrum male mating type). Apparently, pollen size and male mating type are normally under sporophytic control.

This finding caused Dulberger (1975) to suggest that the developmental controls for pollen size and male incompatibility phenotype are somehow associated during early sporogenesis. However, Dulberger (1993) accepted that male incompatibility phenotype is independent of pollen size in heteromorphic genera such as Linum which lack a pollensize dimorphy (Murray, 1986). Ganders (1979) found no relationship between pollen-size ratios and style-length ratios in 24 heteromorphic species, and Richards (1993) pointed out for Primula that pollen grain volumes differ between species by a factor of 500 , yet some of the smallest grains grow down some of the longest styles. It seems clear that pollen size has no direct relationship to the length of legitimate styles.

It seems inherently unlikely that the same gene produces a product which controls both pollen size and male incompatibility phenotype. Richards (1993) suggests that these features may in fact be controlled by two different but closely linked genes, and infers that recombinants between these should be found in the future, although they had not yet been reported.
In the present paper, a recombinant between genes controlling male incompatibility phenotype and the dominance control of pollen size is reported. This recombinant also includes a thrumlinked lethal, and a style-length modifier, so that a much more detailed configuration of the supergene can be proposed.

\section{Materials and methods}

\section{Origin of the recombinant strain}

Plants of 'polyanthus' Primula (P. $\times$ tommasinii Gren. $\&$ Godron) were grown from one packet of seed of horticultural origin in 1985 for class teaching purposes. During class examination of this material, it became apparent that a few of the pin morph plants were abnormal, producing a mixture of pin-sized and thrum-sized pollen grains, and possessing a shorter style than did normal pin plants. These plants also appeared to be self-fertile. When we started to study these plants in detail in 1989 , seven of the original generation of 176 plants were of this type, which we termed $\mathrm{P}^{*}$ (Table 1).

\section{Cultivation}

Three further generations were raised, making a total of four generations that were studied. Each generation was kept quite separate in the crossing programme. Plants were usually grown in insectproof conditions under glass $(15 \mathrm{~h}$ day minimum, $12-16^{\circ} \mathrm{C}$ range) on self-watering benches. During hot conditions after flowering they were placed outside. Seed was collected when ripe, counted, weighed, and undeveloped ovules were also scraped out of capsules and carefully counted. Seed was sown immediately without pretreatment into 2:1

Table 1 Numbers of pin morph (P), thrum morph (T) and abnormal pin morph ( $\left.\mathrm{P}^{*}\right)$ seedlings of Primula $\times$ tommasinii raised to flowering in each generation

\begin{tabular}{lrrrr}
\hline Generation & $\mathrm{P}$ & $\mathrm{T}$ & $\mathrm{P}$ & $n$ \\
\hline 1 & 136 & 33 & 7 & 176 \\
2 & 93 & 89 & 39 & 221 \\
3 & 73 & 31 & 57 & 164 \\
4 & 80 & 11 & 93 & 184 \\
\hline
\end{tabular}

Seedlings in generation 1 resulted from commercially produced seed.

Generations 2, 3 and 4 resulted from various types of controlled crosses. 
proprietary ericaceous compost: fine granite grit in plastic trays $12 \times 16 \mathrm{~cm}$, covered with $0.5 \mathrm{~cm}$ of fine grit. All plants which germinated did so within 20 days. When the first true leaf attained a length of $8 \mathrm{~cm}$, seedlings were transplanted into $10 \mathrm{~cm}$ plastic pots filled with the same compost, and moved into $13 \mathrm{~cm}$ pots at about two months. Most plants first flowered at about 6 months, when morphological measurements and crosses/selfs were made. Conditions within and between generations were kept as constant as possible. Generation time varied somewhat between generations according to the season.

\section{Crossing programme and data collection}

Individual flowers lasted about 15 days. At between three and six days after a flower opened, style length (ovary top to stigma base), mean length of 10 stigma papillae, 10 central style cells, the mean diameter of 50 pollen grains stained in aceto-carmine, the maximum dimensions of the stigma, and the distance from the ovary top to the median anther position were measured microscopically for two flowers from each plant.

To make crosses and selfs, the corolla was removed from the female parent together with the epipetalous stamens during the first two days of the life of the flower, before anther dehiscence occurred. Stigmas were checked for receptivity (swollen stigma papillae), and pollen contamination with $\mathrm{a} \times 20$ lens. Crosses were made from dehiscent anthers using a fine brush, and the pollinated flowers were labelled. Most crosses and selfs either involved $\mathrm{P}^{*}$ plants or were made as controls.

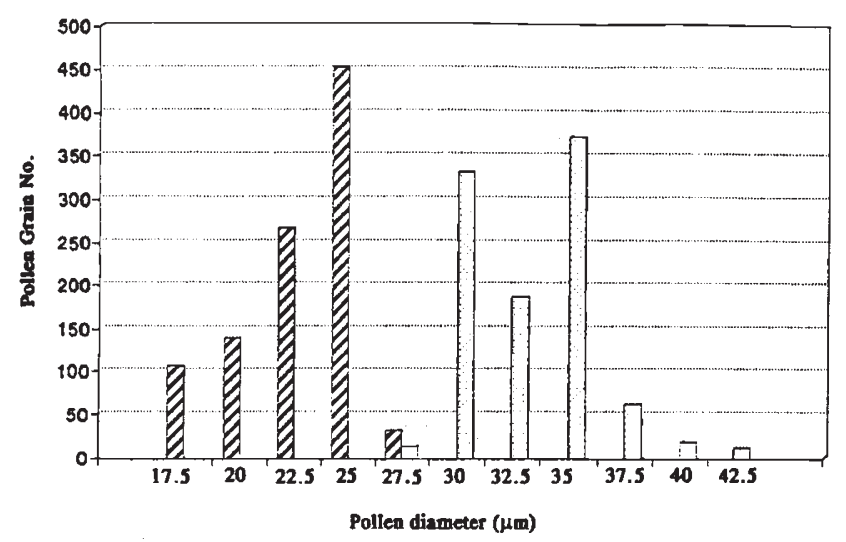

Fig. 1 Distributions of pollen diameters for 20 pin plants (shaded) and 20 thrum plants (unshaded) of Primula $\times$ tommasinii (50 grains/plant).
Studies of pollen grain germination and pollen tube growth on stigmas $72 \mathrm{~h}$ after pollination were made using the fluorescence microscopy method described in Wedderburn \& Richards (1990).

\section{Results}

\section{Pollen diameter}

Except in generation 3 for pins and thrums, average pollen diameter did not differ significantly between generations for a given morph (Table 2). In any generation, each of the three morphs differed significantly for pollen diameter. Pins had the smallest pollen and thrum the largest pollen, $\mathrm{P}^{*}$ plants taking an intermediate position. All morphs had a high level of pollen stainability, in excess of 90 per cent.

Over all generations, the distribution of pollen diameter (Fig. 1) was unimodal but skewed in pins (mean $23.73 \mu \mathrm{m}$, mode $25 \mu \mathrm{m}$ ); unimodal in thrums (mean and mode $36.30 \mu \mathrm{m}$ ); but strongly bimodal in $\mathrm{P}^{*}$ (Fig. 2). For $1000 \mathrm{P}^{*}$ grains measured from $20 \mathrm{P}^{*}$ plants in generation 3 , those measuring $27.0 \mu \mathrm{m}$ or less in diameter were classified as 'pin type' $(n=486)$ and those measuring $27.1 \mu \mathrm{m}$ or more were classified as 'thrum type' $(n=512)$, using the data from pin and thrum plants (Fig. 1) for classificatory limits. $\chi_{1}^{2}=0.76$, (NS) against the expectation of equal numbers of the two pollen size classes in the $\mathrm{P}^{*}$ plants. For these $\mathrm{P}^{*}$ pollen size classes, the 'pin type' grain mean diameter was $23.82 \mu \mathrm{m}$ and that of 'thrum type' pollen $33.82 \mu \mathrm{m}$. These means do not differ significantly from overall mean diameters of pin $\left(t_{71}=2.7\right)$ and thrum $\left(t_{71}=1.7\right)$ pollen.

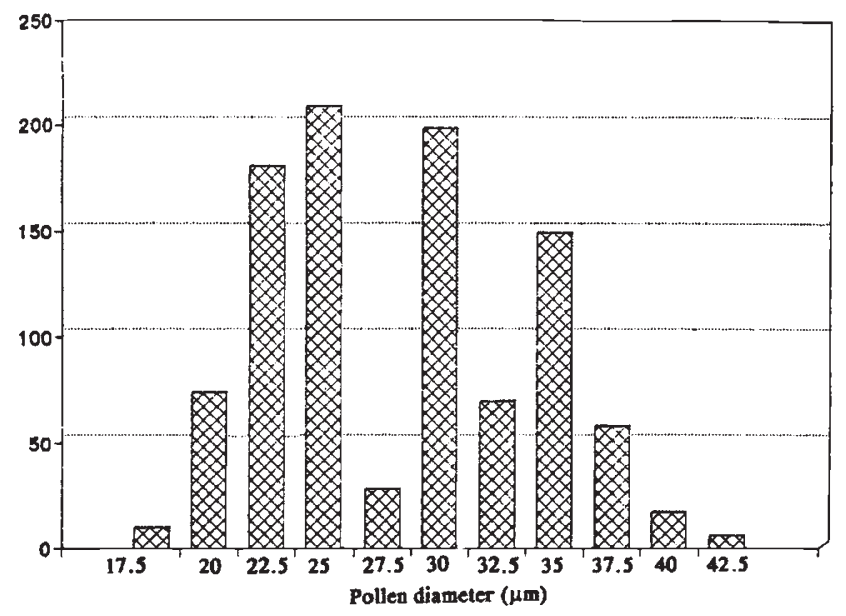

Fig. 2 Distribution of pollen diameters for $20 \mathrm{P}^{*}$ plants of Primula $\times$ tommasinii (50 grains/plant). 
Table 2 Mean $\pm 2 \times$ standard error for average pollen diameter $(\mu \mathrm{m})$, style length $(\mathrm{mm})$, stigma papilla length $(\mu \mathrm{m})$, style cell length $(\mu \mathrm{m})$, and stigma length/width for pins $(\mathrm{P})$, thrums $(\mathrm{T})$ and abnormal pins $\left(\mathrm{P}^{*}\right)$ in each generation of Primula $\times$ tommasinii

\begin{tabular}{|c|c|c|c|c|c|c|c|}
\hline Generation & Type & $n$ & $\begin{array}{c}\text { Pollen } \\
\text { diameter }\end{array}$ & $\begin{array}{l}\text { Style } \\
\text { length }\end{array}$ & $\begin{array}{l}\text { Papilla } \\
\text { length }\end{array}$ & $\begin{array}{l}\text { Style } \\
\text { cell }\end{array}$ & $\begin{array}{c}\text { Stigma } \\
L / W\end{array}$ \\
\hline 1 & $P$ & 49 & $\begin{array}{r}24.4 \\
\pm 0.6\end{array}$ & $\begin{array}{r}14.6 \\
\pm 0.6\end{array}$ & $\begin{array}{l}109.2 \\
\pm 7.5\end{array}$ & $\begin{array}{r}96.7 \\
\pm 4.7\end{array}$ & $\begin{array}{r}0.81 \\
\pm 0.08\end{array}$ \\
\hline 1 & $\mathrm{P}^{*}$ & 7 & $\begin{array}{c}29.7^{*} \\
\pm 1.6\end{array}$ & $\begin{array}{r}13.4 \\
\pm 0.9\end{array}$ & $\begin{array}{c}76.2^{*} \\
\pm 5.6\end{array}$ & $\begin{array}{c}75.5^{*} \\
\pm 5.7\end{array}$ & $\begin{array}{r}0.96 \\
\pm 0.10\end{array}$ \\
\hline 1 & $\mathrm{~T}$ & 30 & $\begin{array}{r}39.5 \\
\pm 1.9\end{array}$ & $\begin{array}{r}7.8 \\
\pm 0.5\end{array}$ & $\begin{array}{r}29.2 \\
\pm 4.2\end{array}$ & $\begin{array}{r}59.8 \\
\pm 4.9\end{array}$ & $\begin{array}{r}0.60 \\
\pm 0.08\end{array}$ \\
\hline 2 & $P$ & 49 & $\begin{array}{r}24.8 \\
\pm 1.1\end{array}$ & $\begin{array}{r}14.0 \\
\pm 0.5\end{array}$ & $\begin{array}{l}105.2 \\
\pm 8.2\end{array}$ & $\begin{array}{l}102.7 \\
\pm 4.5\end{array}$ & $\begin{array}{r}0.86 \\
\pm 0.10\end{array}$ \\
\hline 2 & $\mathrm{P}^{*}$ & 38 & $\begin{array}{c}32.4^{*} \\
\pm 1.9\end{array}$ & $\begin{array}{l}13.0^{*} \\
\pm 0.4\end{array}$ & $\begin{array}{r}75.5^{*} \\
\pm 4.2\end{array}$ & $\begin{array}{l}79.0^{*} \\
\pm 4.2\end{array}$ & $\begin{array}{r}0.96 \\
\pm 0.09\end{array}$ \\
\hline 2 & $\mathrm{~T}$ & 30 & $\begin{array}{r}39.5 \\
\pm 0.7\end{array}$ & $\begin{array}{r}8.5 \\
\pm 0.6\end{array}$ & $\begin{array}{r}26.2 \\
\pm 1.6\end{array}$ & $\begin{array}{r}60.7 \\
\pm 4.4\end{array}$ & $\begin{array}{r}0.58 \\
\pm 0.05\end{array}$ \\
\hline 3 & $P$ & 49 & $\begin{array}{r}20.5 \\
\pm 0.6\end{array}$ & $\begin{array}{r}14.0 \\
\pm 0.6\end{array}$ & $\begin{array}{l}116.7 \\
\pm 5.7\end{array}$ & $\begin{array}{r}95.5 \\
\pm 4.0\end{array}$ & $\begin{array}{r}0.82 \\
\pm 0.06\end{array}$ \\
\hline 3 & $\mathrm{P}^{*}$ & 45 & $\begin{array}{r}28.9^{*} \\
\pm 3.7\end{array}$ & $\begin{array}{l}12.6^{*} \\
\pm 0.6\end{array}$ & $\begin{array}{c}78.7^{*} \\
\pm 4.9\end{array}$ & $\begin{array}{r}76.7^{*} \\
\pm 4.0\end{array}$ & $\begin{array}{r}0.95^{*} \\
\pm 0.05\end{array}$ \\
\hline 3 & $\mathrm{~T}$ & 30 & $\begin{array}{r}33.0 \\
\pm 0.4\end{array}$ & $\begin{array}{r}8.2 \\
\pm 0.7\end{array}$ & $\begin{array}{r}28.7 \\
\pm 4.0\end{array}$ & $\begin{array}{r}56.2 \\
+3.5\end{array}$ & $\begin{array}{r}0.57 \\
\pm 0.09\end{array}$ \\
\hline 4 & $P$ & 49 & $\begin{array}{r}25.3 \\
\pm 1.6\end{array}$ & $\begin{array}{r}14.2 \\
\pm 0.4\end{array}$ & $\begin{array}{l}113.0 \\
\pm 6.8\end{array}$ & $\begin{array}{r}98.5 \\
\pm 4.3\end{array}$ & $\begin{array}{r}0.95 \\
\pm 0.08\end{array}$ \\
\hline 4 & $\mathrm{P}^{*}$ & 45 & $\begin{array}{c}31.7^{*} \\
\pm 0.8\end{array}$ & $\begin{array}{c}12.9^{*} \\
\pm 0.4\end{array}$ & $\begin{array}{r}75.7^{*} \\
\pm 3.8\end{array}$ & $\begin{array}{r}77.5^{*} \\
\pm 3.5\end{array}$ & $\begin{array}{r}0.97 \\
\pm 0.07\end{array}$ \\
\hline 4 & $\mathrm{~T}$ & 10 & $\begin{array}{r}35.2 \\
\pm 1.8\end{array}$ & $\begin{array}{r}8.7 \\
+1.0 \\
\end{array}$ & $\begin{array}{r}31.2 \\
\pm 4.9\end{array}$ & $\begin{array}{r}57.0 \\
\pm 4.1\end{array}$ & $\begin{array}{r}0.59 \\
\pm 0.18\end{array}$ \\
\hline
\end{tabular}

T differs significantly from $\mathrm{P}$ and from $\mathrm{P}^{*}$ for each attribute in each generation. Where $P^{*}$ differs from $P$ significantly for an attribute within a generation $(t$-test, $P<0.05$ ), this is noted by an asterisk against the mean.

\section{Pollen germination}

Pin mothers $(n=16)$ and $\mathrm{P}^{*}$ mothers $(n=9)$ were pollinated with $\mathrm{P}^{*}$ pollen, and pollen germination was examined under the UV microscope. Different fathers and mothers were used for each cross. Each pollen grain was measured and classified as pin type or thrum type as it was encountered on the stigma, and the presence or absence of pollen germination noted.

No significant difference between pollen-size types in the proportion of grains germinating was noted either on pin stigmas or on $\mathrm{P}^{*}$ stigmas (Table 3 ).

\section{Compatibility of $P^{*}$ in crosses and selfs}

Pin mothers set fertile seed when pollinated with $\mathrm{P}^{*}$ pollen, but not when selfed (Table 4). In contrast, thrum mothers set no seed when pollinated with $\mathrm{P}^{*}$ pollen. $\mathrm{P}^{*}$ selfs also set some fertile seed. As a female parent, $P^{*}$ mothers set fertile seed when crossed with thrum fathers, but no seed was set when they were crossed with pin fathers.

$\mathrm{P}^{*}$ tended to father fewer seeds on pin and $\mathrm{P}^{*}$ mothers than did thrums, and this seed tended to be less viable. However, unlike the legitimate 'controls', most of these crosses were made in generations 3 and 4 , when the overall fertility and viability of $\mathrm{P}^{*}$ and pins fell after all crosses, apparently as a result of inbreeding depression (Kurian, 1996).

\section{Inheritance of $P^{*}$}

Of the total number of offspring raised to flowering from $\mathrm{P}^{*}$ selfs, 61.7 per cent were $\mathrm{P}^{*}$ and the remain- 
Table 3 Numbers of pin-type grains and thrum-type grains (classified according to pollen diameter) germinating on pin and $\mathrm{P}^{*}$ stigmas of Primula $\times$ tommasinii $72 \mathrm{~h}$ after pollination

\begin{tabular}{lccc}
\hline & \multicolumn{2}{c}{$\mathrm{P}^{*}$ pollen type } & \\
\cline { 2 - 3 } & Pin-type & Thrum-type & \\
\hline Pin stigma & & & \\
Germinated & 87 & 73 & \\
Not germinated & 88 & 72 & $\chi_{1}^{2}=0.01$ \\
P* stigma & & & \\
Germinated & 45 & 55 & \\
Not germinated & 50 & 50 & $\chi_{1}^{2}=0.50$ \\
\hline
\end{tabular}

Table 5 Inheritance of the $\mathrm{P}^{*}$ phenotype of Primula $\times$ tommasinii after selfs and after crosses onto pin mothers

\begin{tabular}{|c|c|c|c|c|}
\hline \multirow{2}{*}{$\begin{array}{l}\text { Type of } \\
\text { cross }\end{array}$} & \multicolumn{2}{|c|}{ Type of offspring } & \multirow[b]{2}{*}{ Total } & \multirow[b]{2}{*}{$\chi^{2}$} \\
\hline & $\mathrm{P}^{*}$ & Pin & & \\
\hline $\mathrm{P}^{*}$ self & 50 & 31 & 81 & $\begin{array}{l}0.88^{1} \mathrm{NS} \\
7.61^{2} P<0.006 \\
4.46^{3} P<0.02\end{array}$ \\
\hline $\mathbf{P} \times \mathrm{P}^{*}$ & 139 & 133 & 272 & $0.13^{3} \mathrm{NS}$ \\
\hline
\end{tabular}

${ }^{1}$ Tested against a $2: 1$ ratio; ${ }^{2}$ tested against a $3: 1$ ratio; ${ }^{3}$ tested against a $1: 1$ ratio.

Table 4 Average percentages in Primula $\times$ tommasinii of seed set, of set seed which germinated, and of germinated seedlings which flowered, after various types of crosses and selfs over four generations

\begin{tabular}{|c|c|c|c|c|c|c|c|c|c|}
\hline & \multicolumn{6}{|c|}{ Types of cross (female parent first) } & \multirow[b]{2}{*}{$P$ self } & \multirow[b]{2}{*}{$\mathrm{T}$ self } & \multirow[b]{2}{*}{$\mathrm{P}^{*}$ sel } \\
\hline & $\mathrm{T} \times \mathrm{P}$ & $\mathrm{P} \times \mathrm{T}$ & $\mathrm{P}^{*} \times \mathrm{T}$ & $\mathrm{P} \times \mathrm{P}^{*}$ & $\mathrm{P}^{*} \times \mathrm{P}$ & $\mathrm{T} \times \mathrm{P}^{*}$ & & & \\
\hline$n$ & 16 & 15 & 12 & 89 & 33 & 21 & 22 & 15 & 85 \\
\hline Seed set \% & 77.9 & 81.3 & 79.6 & 50.8 & 0 & 0 & 0 & 48.9 & 30.6 \\
\hline Seed germ. \% & 59.4 & 60.2 & 54.7 & 31.6 & 0 & 0 & 0 & 0 & 18.9 \\
\hline Seedling viability & 92.5 & 90.1 & 94.2 & 79.8 & 0 & 0 & 0 & 0 & 34.5 \\
\hline
\end{tabular}

$n$ refers to the number of crosses analysed. The numbers of ovules, seeds and seedlings analysed varied within treatments, but exceeded 50 in all cases.

der were pins (Table 5). Tested against an expected ratio of $3: 1, \chi^{2}=7.61, P<0.006$. Against an expected ratio of $2: 1, \chi^{2}=0.89$, NS. Against an expected ratio of $1: 1, \chi^{2}=5.44, P<0.02$.

Where $\mathrm{P}^{*}$ was used as a male parent to pin mothers, 51.1 per cent of the offspring were $\mathrm{P}^{*}$. Tested against an expected ratio of $1: 1, \chi^{2}=0.13$, NS.

\section{Style length, stigma papilla length, style cell length and stigma shape}

$\mathrm{P}^{*}$ plants had styles that were shorter than those of pins (significantly so in generations 2, 3 and 4) but which were significantly longer than those of thrums in each generation (Table 2). $\mathrm{P}^{*}$ plants also had stigma papillae which were significantly shorter than those of pins, but significantly longer than those of thrums in each generation (Table 2). In addition, the style cells of $\mathrm{P}^{*}$ plants were significantly shorter than those of pin plants, but significantly longer than those of thrum plants in each generation (Table 2).

Although the length/width ratio of the stigma of
P* plants tended to be greater than that of pins in each generation, in no case was this difference significant at the 5 per cent level (Table 2). However, thrums had significantly lower length/width ratios than both pins and $\mathrm{P}^{*}$ plants in each generation.

There was a significantly positive relationship between style length and stigma papilla length when pin and $\mathrm{P}^{*}$ plants were considered together (Fig. 3).

\section{Discussion}

Distylous Primula species are invariably dimorphic for pollen diameter, so that pin individuals and thrum individuals have distinct, usually nonoverlapping distributions for pollen diameter. However, individuals of the $\mathrm{P}^{*}$ breeding system morph studied here always had half of the pollen with a size distribution typical of pin morph plants and the other half with a size distribution typical of thrum morph plants (Fig. 2). The means and distributions of diameters of the two types of pollen found in $\mathrm{P}^{*}$ plants were statistically inseparable from those of 
'normal' pins and thrums in the same strain.

The simplest explanation for this condition, which seems to have no published precedent, is that $\mathrm{P}^{*}$ plants possess a chromosome which has inherited the thrum morph allele which controls pollen size, but which has lost the dominance control for pollen size. If $\mathrm{P}^{*}$ plants are heterozygous for the $\mathrm{P}^{*}$ chromosome and for a pin chromosome, pollen grains of the $\mathrm{P}^{*}$ morph which carry the $\mathrm{P}^{*}$ chromosome might thus have the same diameter as those of thrums, whereas those carrying the pin chromosome might have the same diameter as those of pins.

This model is supported by the inheritance of the $\mathrm{P}^{*}$ morph. When $\mathrm{P}^{*}$ were crossed to pin mothers, offspring invariably segregated at $1: 1 \mathrm{P}^{*}$ :pin (Table 5). As pins are homozygous for the pin chromosome, all $\mathrm{P}^{*}$ morphs must therefore be heterozygous for the pin chromosome and the (dominant) $\mathrm{P}^{*}$ chromosome. Interestingly, this model suggests that in the absence of dominance control, pollen size is controlled gametophytically. It suggests that in the absence of tapetal override, pollen grains can determine their own size.

Although $\mathrm{P}^{*}$ individuals are self-fertile, they never gave rise to individuals with uniformly thrum-sized pollen when selfed. Instead, the proportion of offspring of a $\mathrm{P}^{*}$ self approached the ratio 2:1 $\mathrm{P}^{*}$ :pin much more closely than the ratio $3: 1 \mathrm{P}^{*}$ :pin. From these results, we infer that $\mathrm{P}^{*}$ homozygotes are not viable. As thrum homozygotes also appear to be inviable in most primulas, we suggest that the $\mathrm{P}^{*}$ chromosome has inherited a recessive lethal gene from the thrum chromosome in linkage with the gene $P$ which controls thrum morph pollen size.

$\mathrm{P}^{*}$ plants are self-fertile, and act as fertile fathers to pin mothers, although these selfs and crosses are not as fertile as are legitimate (pin $\times$ thrum, thrum $\times$ pin) crosses from earlier generations. Pin-sized pollen and thrum-sized pollen from $\mathrm{P}^{*}$ fathers germinate equally well as each other on both $\mathrm{P}^{*}$ stigmas and pin stigmas. In $P$. vulgaris and $P$. veris (the parents of $P$. tommasinii) between one-half and two-thirds of illegitimate pin pollen inhibition takes place at the stigma surface (Wedderburn \& Richards, 1990). If male self-incompatibility recognition was functionally or developmentally associated with pollen size, we would expect that the large, thrum-sized pollen grains of a $\mathrm{P}^{*}$ would have germinated on pin and $\mathrm{P}^{*}$ stigmas more readily than did small, pin-sized pollen grains from the same father. We did not find this (Table 3). Instead, all $\mathrm{P}^{*}$ pollen grains behaved on pin stigmas in a manner typical of pollen grains from a thrum father. Also, it appears from the inheritance of the $\mathrm{P}^{*}$ morph (Table 5), discussed above, that the pin-sized pollen of $\mathrm{P} *$ fertilizes pin and $\mathrm{P}^{*}$ mothers just as readily as does thrum-sized pollen from the same father.

From these results we conclude that pollen size is not intimately associated with pollen compatibility relationships, and that these two attributes are under separate genetic control. Although the $\mathrm{P}^{*}$ morph has apparently inherited thrum-type male characteristics for both pollen size and compatibility, the absence of dominance control for pollen size has enabled us to show that the small pin-type pollen grains still apparently behave as if they were thrum with respect to compatibility relationships.

Although $\mathrm{P}^{*}$ pollen displayed a thrum-type male compatibility phenotype, $\mathrm{P}^{*}$ stigmas showed a pin-type female compatibility phenotype (Table 4). When crossed with pollen from thrum morphs, $\mathrm{P}^{*}$ mothers produced seed with a set and viability indistinguishable from those resulting from legitimate crosses. However, when crossed with the pollen of 'normal' pins, $\mathrm{P}^{*}$ mothers never set seed.

These results clearly demonstrate that male compatibility phenotype is under separate genetic control from female compatibility phenotype in Primula. This supports findings from long homostyle recombinants which have a pin-type female compatibility phenotype, but a thrum-type male incompatibility phenotype (Crosby, 1949; Ernst, 1950; Richards, 1986; Wedderburn \& Richards, 1992).

$\mathrm{P}^{*}$ flowers displayed an approach herkogamy, as do the flowers of pins, but the styles were invariably shorter than those of pins, although still much longer than those of thrums (Table 2). From this result we suggest that at least two linked loci may

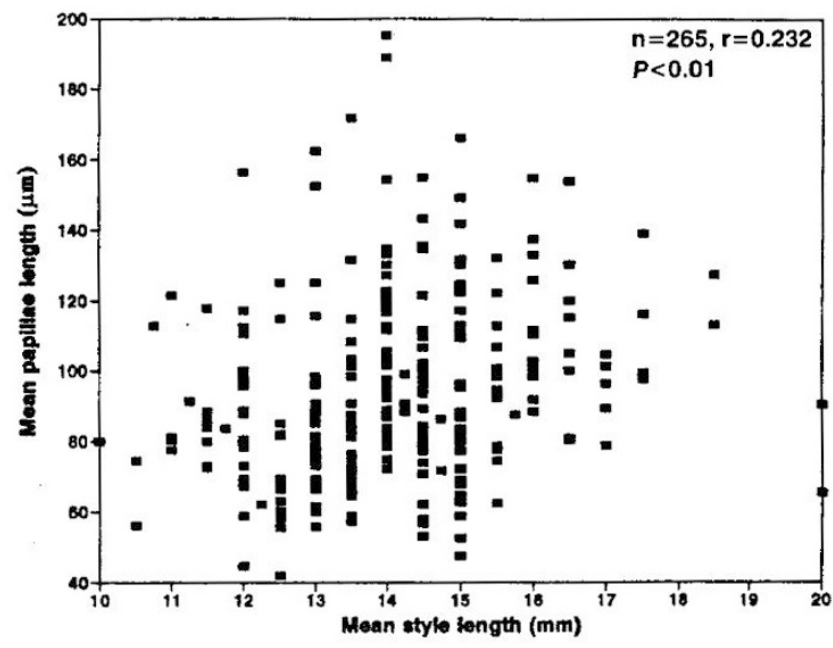

Fig. 3 Average style lengths ( $x$-axis) and stigma papilla lengths ( $y$-axis) for 265 pin and $\mathrm{P}^{*}$ plants of

Primula $\times$ tommasinii.

(c) The Genetical Society of Great Britain, Heredity, 78, 383-390. 
control style length in Primula in an additive way. It seems that $\mathrm{P}^{*}$ plants may carry the dominant shortstyle allele typical of thrums at one locus, but longstyle allele(s) typical of pins at the other locus(i), so that the $\mathrm{P}^{*}$ style is shortened relative to that of pins, but is still substantially longer than that of thrums. Mather (1950) identified a gpa-linked locus, at which a mutant ('Primrose Queen') shortens the length of pin stigmas in $P$. sinensis, and this could be homologous with the style-shortening gene reported here.

$\mathrm{P}^{*}$ gynoecia had correspondingly short stigma papillae and central style cells (Table 2), although once again these were much longer than in thrums. Al Wadi \& Richards (1993) showed that these attributes were closely associated with style length, even in non-distylous Primula species, and suggested that they represent developmental correlates of distyly. Our results here tend to confirm this hypothesis (Fig. 3).

However, the length/width ratio of $\mathrm{P}^{*}$ stigmas was invariably greater than that of pins (although not significantly so) whereas that of thrums was significantly less than that of pins (Table 2). From this, we suggest that the genetic control of stigma shape is independent of that of style length.

The $\mathrm{P}^{*}$ morph was first identified by the strikingly dimorphic size of its pollen. Subsequent study has shown that $\mathrm{P}^{*}$ plants consistently differ from 'normal' pins in a number of attributes:

1 half the pollen has the same diameter as thrum pollen;

2 all the pollen has thrum-type male compatibility phenotype;

3 the styles, stigma papillae and style cells are shorter, although much longer than those of thrums; 4 no homozygous mating system genotypes occur; 5 also, in comparison with thrums, the dominance of thrum pollen diameter control has been lost.

We consider that it is highly improbable that such a complex suite of associated characteristics could have arisen from a single mutation, or that several mutations coexist in $\mathrm{P}^{*}$ plants in the absence of intermediates. It is very much more likely that the $\mathrm{P}^{*}$ morph results from a recombination within the heteromorphy supergene, analogous to those which have resulted in short and long homostyles.

$\mathrm{P}^{*}$ plants resemble 'normal' pins for female compatibility phenotype, anther position, and in part for style length and associated characters. Thus, the loci $G / g$ and $A / a$ are apparently nonrecombinant in the $\mathrm{P}^{*}$ chromosome which thus carries the alleles $g$ and $a$. Also, we assume that the nondominance phenotype for pollen-size dominance control will be pin linked, and is thus also nonrecombinant. We term this locus $\mathrm{Mpm} / \mathrm{mpm}$, and the pin-linked nonrecombinant allele $\mathrm{mpm}$.

Thus, for the $\mathrm{P}^{*}$ chromosome, we identify the nonrecombinant loci as:

$1 \mathrm{G} / \mathrm{g}$, controls female compatibility phenotype, and style length (in part); $\mathrm{P}^{*}$ nonrecombinant allele $g$; $2 A / a$, controls anther position; $\mathrm{P}^{*}$ nonrecombinant allele $a$;

$3 \mathrm{Mpm} / \mathrm{mpm}$, controls dominance for pollen size; $\mathrm{P}^{*}$ nonrecombinant allele $\mathrm{mpm}$ (position uncertain).

It follows that the following presumptive loci are recombinant for the $\mathrm{P}^{*}$ chromosome, being derived from the thrum chromosome; the relative positions of all of these loci is uncertain:

$1 \mathrm{Pp} / \mathrm{pp}$, controls pollen size; $\mathrm{P}^{*}$ recombinant allele $P p$;

$2 \mathrm{Pm} / \mathrm{pm}$, controls male compatibility phenotype; $\mathrm{P}^{*}$ recombinant allele $P m$;

$3 \mathrm{~L} / \mathrm{l}$, controls thrum homozygote lethality; $\mathrm{P}^{*}$ recombinant allele $l$;

$4 \mathrm{Gm} / \mathrm{gm}$, contributes to stylar length; $\mathrm{P}^{*}$ recombinant allele $G m$;

5 ( Mpp/mpp controls dominance of male incompatibility phenotype).

The behaviour of the $\mathrm{P}^{*}$ morph provides good evidence for the existence of four of these recombinant loci, and it is very unlikely that developmental links or epistasis would cause any one locus to control more than one of these functions. This is certainly the case for the loci $P p / p p$ and $P m / p m$. However, it is quite likely that the dominance of male compatibility phenotype is a function of the means by which an anther endows its pollen with its compatibility phenotype (Shivanna et al., 1983). If this is so, the dominance of pollen compatibility phenotype would not be under separate genetic control, unlike dominance control for pollen-size phenotype.

Using the results of Ernst (1936, 1955), Lewis (1954) and Dowrick (1956) identified three recombinable loci in the Primula heteromorphy supergene. Although Ernst had given these the presumptive order $G A P$, on the basis of double recombinants being the rarest backcross phenotypes, Dowrick suggested that GPA was the more likely order. Lewis \& Jones (1993) have reanalysed Ernst's data, showing for the members of Primula subgenus Auriculastrum with which Ernst was working, that $G P A$ is almost certainly the correct order for these loci. 
However, for our plants, the loci $G / g$ and $A / a$ were nonrecombinant, whereas the locus $P / p$ was recombinant, so that unless our plants originated from a double recombinant, the order of these loci must be GAP. As P. $\times$ tommasinii (subgenus Primula) is only very distantly related to subgenus Auriculastrum (Richards, 1993), it may well be that the order of these loci within the supergene differs for the two taxa.

The $\mathrm{P}^{*}$ recombinant allows us to suggest that the Primula heteromorphy supergene consists of at least seven loci. It has also demonstrated for the first time that pollen size and pollen compatibility phenotypes have independent functions and controls in heteromorphic Primula; that the genetic control of dominance for pollen grain size is recombinable with the genetic control for pollen size; that pollen size can be controlled gametophytically; and that stigma shape is not a developmental correlate of style length.

Further, the $\mathrm{P}^{*}$ recombinant has confirmed earlier suggestions that for heteromorphic Primula, style length and associated characters are controlled by at least two loci; that stigma papilla length and style cell length are developmental correlates of style length; that male and female compatibility phenotypes are under separate, recombinable genetic control; and that a recessive lethal is linked to the thrum chromosome, and had been recombined onto the $\mathrm{P}^{*}$ recombinant chromosome.

\section{References}

AL WADI, H. AND RiCHARDS, A. J. 1993. Primary homostyly in Primula L. subgenus Sphondylia (Duby) Rupr. and the evolution of distyly in Primula. New Phytol., 124, 329-338.

CROSBY, J. L. 1949. Selection of an unfavourable genecomplex. Evolution, 3, 212-230.

DOWRICK, v. P. J. 1956. Heterostyly and homostyly in Primula obconica. Heredity, 10, 219-236.

DULBERGER, R. 1975. $S$ gene action and the significance of characters in the heterostylous syndrome. Heredity, 35, 407-415.

DULBERGER, R. 1993. Floral polymorphisms and their functional significance in the heterostylous syndrome.
In: Barrett, S. C. H. (ed.) Evolution and Function of Heterostyly, pp. 41-84. Springer-Verlag, Berlin.

ERNST, A. 1936. Weitere Untersuchungen zur Phänanalyse, zum Fertilitätsproblem und zur Genetik heterostyler Primeln. II. Primula hortensis Wettst. Arch. J. K.-Stift. Ver., Soc. Rass., 11, 1-280.

ERNST, A. 1950. Resultate aus Kreuzungen zwischen der tetraploiden, monomorphen Pr. japonica und diploiden, mono- und dimorphen Arten der Sektion Candelabra. Arch. J. K.-Stift. Ver., Soc. Rass., 25, 135-236.

ERNST, A. 1955. Untersuchungen zur Phänanalyse, zum Fertilitätsproblem und zur Genetik heterostyler Primeln 4. Die F2-F5-Nachkommenschaften der Bastarde Pr. (hortensis $\times$ viscosa). Arch. J. K.-Stift. Ver., Soc. Rass., 30, 13-137.

ERNST, A. 1957. Austausch und Mutation im Komplex-gen für Blutenplastik und Inkompatibilität bei Primula. $Z$. indukt. Abstamm. Vererb., 88, 517-599.

GANDERS, F. R. 1979. The biology of heterostyly. N. Z. J. Bot., 17, 607-635.

KURIAN, v. 1996. Investigation on the Genetic Control of the Primula L. Heteromorphy Supergene. Ph. D. Thesis, University of Newcastle upon Tyne.

LEWIS, D. 1954. Comparative incompatibility in angiosperms and fungi. Adv. Gen., 6, 235-245.

LEWIS, D. AND JONES D. A. 1993. The genetics of heterostyly. In: Barrett, S. C. H. (ed.) Evolution and Function of Heterostyly, pp. 129-150. Springer-Verlag, Berlin.

MATHER, K. 1950. The genetical architecture of heterostyly in Primula sinensis. Evolution, 4, 340-352.

MATHER, K. AND DE WINTON, D. 1941. Adaptation and counteradaptation of the breeding system in Primula. Ann. Bot., 5, 297-311.

MURRAY, B. G. 1986. Floral biology and self-incompatibility in Linum. Bot. Gaz., 147, 327-333.

RICHARDS, A. J. 1986. Plant Breeding Systems, 1st edn. Allen and Unwin, London.

Richards, A. J. 1993. Primula. Batsford, London/Timber, New York.

SHIVANNA, K. R., HESLOP-HARRISON, J. AND HESLOP-HARR1SON, Y. 1983. Heterostyly in Primula. 3. Pollen water economy: a factor in the intramorph incompatibility response. Protoplasma, 117, 175-184.

WEDDERBURN, F. M. AND RICHARDS, A. J. 1990. Variation in within-morph incompatibility inhibition sites in heteromorphic Primula L. New Phytol., 116, 149-162.

WEDDERBURN, F. M. AND RICHARDS, A. J. 1992. Secondary homostyly in Primula L.; evidence for the model of the ' $S$ ' supergene. New Phytol., 121, 649-655. 